\title{
Poor Sleep Quality among Medical Students in International Islamic University Malaysia (IIUM) and Its Association with Mental Health and other Factors
}

\author{
Said $A H^{a}$, Yusof $M Z^{b}$, Mohd FN', Azmi MANH' ${ }^{d}$, Mohd Hanapiah $H^{d}$, Abdullah $A W^{d}$ \\ aDepartment of Family Medicine, Kulliyyah of Medicine, International Islamic University Malaysia. \\ bepartment of Community Medicine, Kulliyyah of Medicine, International Islamic University Malaysia. \\ 'Special Care Dentistry unit, Kulliyyah of Dentistry, International Islamic University Malaysia. \\ ${ }^{\mathrm{d}}$ Final year medical students, Kulliyyah of Medicine, International Islamic University Malaysia.
}

\section{ABSTRACT}

INTRODUCTION: Poor sleep quality is a common problem experienced by medical students worldwide. Therefore, this study aimed to measure the prevalence of poor sleep quality among medical students in International Islamic University Malaysia (IIUM) and its association with mental health and other factors. MATERIALS AND METHODS: A cross-sectional study using convenience sampling was conducted among 500 medical students in IIUM Kuantan. A validated self-reported questionnaire including sociodemographic, socioeconomic, lifestyle, Pittsburgh Sleep Quality Index and Depression Anxiety Stress Score 21 was distributed from $15^{\text {th }}$ July to $31^{\text {st }}$ August 2019. Descriptive statistics were used to measure the prevalence of poor sleep quality. Chi- square test, Fisher's exact test, independent sample T-test, and multiple logistic regression were used to measure the association between risk factors and sleep quality. RESULT: The response rate was $91.2 \%$. The prevalence of poor sleep quality was $59.6 \%$. Multiple logistic regression analysis revealed level of study (clinical year $(A O R=0.44,95 \% \mathrm{Cl}: 0.29-0.66)$ and depression (yes (AOR: $1.71,95 \% \mathrm{Cl}$ 1.03-2.83) contributed independently on poor sleep quality among medical students. There was no significant relationship between tahajjud practice and poor sleep quality. CONCLUSION: More than half of IIUM medical students have poor sleep quality. Those students who were in the pre-clinical year and had depression were independently associated with the occurrence of poor sleep quality. Early intervention is compulsory to overcome this problem among medical students in IIUM.

KEYWORDS: poor sleep quality, medical students, mental health, depression, tahajjud

\section{INTRODUCTION}

Good quality sleep is vital for human beings as it plays a key role in both mental and physical health. For medical students, a good sleep is essential in order to have optimum cognitive function, memory, and decision making to excel and master their learning needs. Besides, good quality sleep will help them to have adequate energy, strength and stamina to endure the tough medical school's learning environment.

Corresponding Author:

Asst. Prof. Dr. Farah Natashah Mohd

Special Care Dentistry Unit,

Department of Maxillofacial Oral Surgery and Oral

Diagnostic, Kuliyyah of Dentistry,

International Islamic University Malaysia,

25200 Kuantan, Malaysia.

Tel no: $+6012-4038242$

Email: fasha@iium.edu.my
An average adult needs 7 to 9 hours of sleep each night, while teenagers and children need, about 9.5 to 16 hours per day respectively. ${ }^{1}$ Entering university life is a big leap for students as they will encounter a lot of challenges such as new schedule, unfamiliar environment, social obligations and academic demands. ${ }^{2}$ Most of them cope with these issues by altering their sleeping time and changing their sleeping habit. ${ }^{3}$

Previous studies in both local and oversea setting had found that the prevalence of poor sleep quality among medical students were high. ${ }^{4-7}$ Apart from that, a big number of them also experience psychological difficulties such as depression, anxiety and stress..$^{4-6,8-11}$ The finding indirectly gives us a clue that medical students are prone to these problems and intervention to resolve them are vital. 
Although there were a few local studies done with similar topics, the fact that each university has its own curriculum and requirement might differently affect the sleep quality. Additionally, all medical students in IIUM in the current academic session were Muslims and most were Malay. This differs significantly to other studies in local universities in which their students were multiracial and multireligion. ${ }^{7,8,12}$ Therefore, this study aimed to find the prevalence of poor sleep quality among medical student of IIUM and its association with mental health and other factors.

\section{METHODOLOGY}

\section{Study design and population}

This was a cross sectional study using convenience sampling conducted from $15^{\text {th }}$ July 2019 until $31^{\text {st }}$ August 2019 among medical students in International Islamic University Malaysia (IIUM) Kuantan Campus. According to a local study among medical students in two public medical universities, the prevalence of poor sleep quality was found to be $63.9 \% .{ }^{4}$ Using the single proportion formula, the minimum required sample size was 425 with the precision of 0.05 , and considering a $20 \%$ non-response rate. We decided to approach all medical students from the first to the fifth year.

\section{Operational definition}

We utilized the Pittsburgh Sleep Quality Index (PSQI) questionnaires to assess the sleep quality in this study. Poor sleep quality is defined as global PSQI score of more than five while good sleep quality defined as a score of five and less. ${ }^{13}$ Tahajjud or qiamullail, meanwhile, is defined as night prayers performed after having gone to sleep at night between Isha' (the night obligatory prayer) and Subuh (the early morning obligatory prayer). ${ }^{14}$

For the mental health component, we assessed the depression, anxiety and stress symptoms among the participants. The symptoms were classified into normal, mild, moderate, severe and extremely severe according to 21-items Depression, Anxiety and Stress Scale (DASS-21). ${ }^{15}$ In this study, the normal level of those three components was defined as no depression, anxiety or stress. Meanwhile, mild to extremely severe level were collectively defined as having depression, anxiety or stress.

\section{Data collection}

All data were collected by a self-administered questionnaire which was divided into three sections. Section A included the sociodemographic and socioeconomic data (year of study, gender, nationality, marital status of student and parents, household income, paternal and maternal educational level), history of family members who had died within the recent 6 months, family history of psychiatric problems, smoking and exercise regularity. As IIUM is an Islamic university, we also included questions regarding the number of pages of Quran read and tahajjud performed in a week to find out its association with poor sleep quality.

In section $B$, the Pittsburgh Sleep Quality Index (PSQI) was used to assess the respondents' sleep quality and sleep disturbances of over a period of one month. PSQI is a validated, self-reported English questionnaire that is able to distinguish 'poor' from 'good' sleep by measuring 7 components; subjective sleep quality, sleep latency, sleep duration, habitual sleep efficiency, sleep disturbances, use of sleeping medication, and daytime dysfunction. ${ }^{13}$ The questionnaire possesses good psychometric properties with cronbach a of 0.793 . Meanwhile, in section $C$, depression, anxiety and stress status were evaluated using a validated, English version of DASS21 questionnaire. ${ }^{15}$ DASS-21 is a well-known and accepted questionnaire which had been well validated for a good many years. The internal consistency reported for the questionnaire was 0.93 .

\section{Data analysis}

SPSS software version 25 was used to perform the data and statistical analysis. For categorical variables, they were described as frequencies and percentages. The numerical variables were recorded as median and interquartile range (IQR) as they were not normally distributed. Bivariable analysis of categorical variables was done using Chi-Square and Fisher's Exact Test. Meanwhile, Mann Whitney U test was used to analyze the not normally distributed numerical variables. A $p$-value of $<0.05$ was considered statistically significant.

Simple and multiple logistic regressions were conducted to assess the relationship between poor sleep quality and one or more independent variables. Multiple logistic regression was performed to identify 
the risk factors and to control for possible confounders. The variables with $p<0.05$ from the bivariate analysis were included for simple and multiple logistic regression analysis. We reported the odds ratio $(O R)$ at $95 \%$ Confidence Interval $(C I)$ to measure the likelihood of associated factors towards poor sleep quality.

\section{Ethical Consideration}

This study was approved by the Kulliyyah of Medicine and IIUM Research Ethics Committee (IREC) with ID no. IREC 2019-146. Participation in this study was entirely voluntary. All participants who agreed to participate in the survey signed a written consent form. In addition, respondents found to have severe or extremely severe level of depression, anxiety or stress from this study were contacted and advised to seek treatment in IIUM family health clinic or any nearby clinic.

\section{RESULTS}

We conveniently selected 100 students from each batch from the first to fifth year medical students. Out of 500 students selected, only 456 students gave their consent and completed the questionnaires. Therefore, the response rate for this study was $91.2 \%$.

The baseline characteristics and mental health status of the respondents were presented in Table 1 . More than half of the respondents were clinical students (year three to year five). More than a quarter of them were from B40 socioeconomic group (27.6\%). $6.8 \%$ of the respondents were from broken family while $7.7 \%$ of them have family history of psychiatric problems. Only one third $(34.4 \%)$ of the respondents were involved in regular physical activity. The median pages of Quran read in a week were 14 pages. On the other hand, the median tahajjud performed was 1 night per week.

In term of mental health status, about $40 \%$ of respondents have depression symptom with most of them having mild to moderate depression. Majority of the respondents have normal stress status (73.7\%) and half of the total respondents have mild to extremely severe anxiety symptoms.
Table I: Baseline characteristics and mental health status of the respondents

\begin{tabular}{|c|c|c|c|}
\hline Characteristics & & $n$ & (\%) \\
\hline \multirow[t]{2}{*}{ Level of study } & $\begin{array}{l}\text { Pre- } \\
\text { clinical }\end{array}$ & 199 & 43.6 \\
\hline & Clinical & 257 & 56.4 \\
\hline \multirow[t]{2}{*}{ Gender } & Male & 124 & 27.2 \\
\hline & Female & 332 & 72.8 \\
\hline \multirow{2}{*}{$\begin{array}{l}\text { Marital status of } \\
\text { dents }\end{array}$} & Single & 452 & 99.1 \\
\hline & Married & 4 & 0.9 \\
\hline \multirow{3}{*}{$\begin{array}{l}\text { Socioeconomic group } \\
(\mathrm{n}=384)\end{array}$} & B40 & 106 & 27.6 \\
\hline & M40 & 118 & 30.7 \\
\hline & $\mathrm{T} 20$ & 160 & 41.7 \\
\hline \multirow[t]{2}{*}{ Marital status of parents } & Married & 425 & 93.2 \\
\hline & $\begin{array}{l}\text { Divorced/ } \\
\text { separated }\end{array}$ & 31 & 6.8 \\
\hline \multirow[t]{2}{*}{ Smoking } & No & 450 & 98.7 \\
\hline & Yes & 6 & 1.3 \\
\hline \multirow{2}{*}{$\begin{array}{l}\text { Regular physical } \\
\text { Activity }(n=453)\end{array}$} & No & 297 & 65.6 \\
\hline & Yes & 156 & 34.4 \\
\hline \multirow{2}{*}{$\begin{array}{l}\text { Family members passed } \\
\text { away within six months }\end{array}$} & No & 409 & 89.7 \\
\hline & Yes & 47 & 10.3 \\
\hline \multirow{2}{*}{$\begin{array}{l}\text { Family history of } \\
\text { psychiatric disorder }\end{array}$} & No & 421 & 92.3 \\
\hline & Yes & 35 & 7.7 \\
\hline $\begin{array}{l}\text { Pages of Quran read } \\
\text { per week } \\
\text { Median (IQR) }\end{array}$ & & & $14(13)$ \\
\hline $\begin{array}{l}\text { Days of tahajjud per week } \\
\text { Median (IQR) }\end{array}$ & & & $1(2)$ \\
\hline \multirow[t]{5}{*}{ Depression } & Normal & 278 & 61.0 \\
\hline & Mild & 66 & 14.5 \\
\hline & Moderate & 64 & 14.0 \\
\hline & Severe & 26 & 5.7 \\
\hline & $\begin{array}{l}\text { Extremely } \\
\text { Severe }\end{array}$ & 22 & 4.8 \\
\hline \multirow[t]{5}{*}{ Anxiety } & Normal & 227 & 49.8 \\
\hline & Mild & 54 & 11.8 \\
\hline & Moderate & 90 & 19.7 \\
\hline & Severe & 38 & 8.3 \\
\hline & $\begin{array}{l}\text { Extremely } \\
\text { severe }\end{array}$ & 47 & 10.3 \\
\hline \multirow[t]{5}{*}{ Stress } & Normal & 336 & 73.7 \\
\hline & Mild & 48 & 10.5 \\
\hline & Moderate & 35 & 7.7 \\
\hline & Severe & 29 & 6.4 \\
\hline & $\begin{array}{l}\text { Extremely } \\
\text { Severe }\end{array}$ & 8 & 1.8 \\
\hline
\end{tabular}

Table II showed the distribution of respondents by sleep quality elements. There were 7 components of sleep quality. More than half $(59 \%)$ of the respondents had described their sleep quality as fairly good. Most of them took less than 15 minutes to sleep $(66.2 \%)$, sleep for less than 6 hours $(62.3 \%)$ per night, had more than $85 \%$ habitual sleep efficiency $(76.1 \%)$, experienced mild sleep disturbances $(73.5 \%)$ and mild daytime dysfunction 
Table II: Distribution of respondent by sleep quality elements $(\mathrm{N}=456)$.

\begin{tabular}{cll}
\hline Element of sleep quality & $\mathbf{n}$ & $\mathbf{( \% )}$ \\
\hline Subjective Sleep Quality & 90 & 19.7 \\
Very good & 269 & 59.0 \\
Fairly good & 84 & 18.4 \\
Fairly bad & 13 & 2.9 \\
Very bad &
\end{tabular}

Sleep Latency (minutes)

$\begin{array}{lll}\text { Less than 15 } & 302 & 66.2 \\ 16-30 & 113 & 24.8 \\ 31-60 & 34 & 7.5 \\ \text { more than } 60 & 7 & 1.5\end{array}$

Sleep Duration (hours)

$\begin{array}{lll}>7 & 36 & 7.9 \\ 6-7 & 136 & 29.8 \\ 5-6 & 161 & 35.3 \\ <5 & 123 & 27.0\end{array}$

Habitual Sleep Efficiency (\%)

$>85$

$75-85$

65-75

$<65$

Sleep Disturbances

$\begin{array}{lll}\text { None } & 56 & 12.3 \\ \text { Mild } & 335 & 73.5 \\ \text { Moderate } & 64 & 14.0 \\ \text { Severe } & 1 & 0.2\end{array}$

Use of Sleeping Medication

$\begin{array}{lll}\text { None } & 442 & 96.9 \\ \text { Mild } & 11 & 2.4 \\ \text { Moderate } & 2 & 0.4 \\ \text { Severe } & 1 & 0.2\end{array}$

Daytime Dysfunction

$\begin{array}{lll}\text { None } & 91 & 20.0 \\ \text { Mild } & 262 & 57.5 \\ \text { Moderate } & 89 & 19.5 \\ \text { Severe } & 14 & 3.1\end{array}$

Causes of Sleep Disturbances $(n=47)$

$\begin{array}{lll}\begin{array}{l}\text { Psychological or } \\ \text { medical } \\ \text { problem }\end{array} & 17 & 36.2 \\ \text { Caffeine } & 15 & 31.9 \\ \text { Exam related } & 7 & 14.9 \\ \begin{array}{l}\text { Academic } \\ \text { requirement }\end{array} & 3 & 6.4 \\ \text { Entertainment } & 3 & 6.4 \\ \text { Environment } & 2 & 4.2\end{array}$

Total PSQI Global Score

$$
\leq 5 \text { (GOOD) }
$$

$>5$ (POOR)
(57.5\%). Only $3 \%$ of them took medication to help them sleep. Most of the reasons for sleep disturbance were psychological or medical-related problem followed by caffeine intake and exam related problem. The prevalence for respondents with global poor sleep quality index (PSQI) of more than five which is considered as having poor sleep quality were $59.4 \%$.

Table III described the association of study variables with sleep quality. Our study found that level of study, number of tahajjud prayer perform and all three components of mental health (depression, anxiety and stress) had significant association with sleep quality.

Simple and multiple logistic regression was used to find the relationship between the level of study, tahajjud, depression, anxiety and stress with poor sleep quality (Table IV). Simple logistic regression analysis shows that respondents who were in the clinical year $(A O R=0.53 \mathrm{Cl} 0.36-0.78, p=0.001)$ and who perform tahajjud $(A O R=0.87 \mathrm{Cl}$ 0.77-0.98, $\mathrm{p}=0.018$ ) were less likely to have poor sleep quality. Meanwhile, respondents with depression $(A O R=2.52$ $\mathrm{Cl} 1.68-3.78, \mathrm{p}<0.001)$, anxiety $(\mathrm{AOR}=2.42 \mathrm{Cl} 1.65$ $3.56, \mathrm{p}<0.001)$ and stress $(A O R=2.88 \mathrm{Cl}$ 1.79-4.63, $\mathrm{p}<0.001$ ) were more likely to have poor sleep quality.

However, multivariate analysis based on logistic regression model revealed that the only significant factors for poor sleep quality were the level of study and depression after adjusting for confounders. Students who were in the clinical year were less likely to have poor sleep quality compared to preclinical students $(\mathrm{AOR}=0.53,95 \% \mathrm{Cl}=0.29-0.66$, $\mathrm{p}<0.001)$. Nonetheless, students with depression symptoms; in comparison with those who did not have depression, have 1.71 times higher risk to have poor sleep quality $(95 \% \mathrm{Cl}=1.03-2.83, \mathrm{p}=0.038)$.

\section{DISCUSSION}

The prevalence of poor sleep quality among our respondents was $59.4 \%$. It was higher compared to studies done in Saudi Arabia and Pakistan. ${ }^{4,5}$ Besides, our study also showed a higher prevalence of poor sleep quality compared to the local studies done among medical students in International Medical University (IMU) and University Tunku Abdul Rahman (UniTAR). ${ }^{6,7}$ However, our respondents have a 
Table III: Association between baseline characteristics with sleep quality

\begin{tabular}{|c|c|c|c|c|c|c|}
\hline \multirow[t]{3}{*}{ Variables } & \multicolumn{4}{|c|}{ Sleep Quality } & \multirow[t]{3}{*}{$x^{2}$} & \multirow[t]{3}{*}{$\mathbf{P}$} \\
\hline & \multicolumn{2}{|c|}{ Good } & \multicolumn{2}{|c|}{ Poor } & & \\
\hline & $\mathbf{n}$ & $(\%)$ & $\mathbf{n}$ & (\%) & & \\
\hline \multicolumn{7}{|l|}{ Level of study } \\
\hline Pre-clinical & 64 & $(32.2)$ & 160 & $(67.8)$ & 10.356 & 0.001 \\
\hline Clinical & 121 & $(47.1)$ & 136 & $(52.9)$ & & \\
\hline \multicolumn{7}{|l|}{ Gender } \\
\hline Male & 45 & $(36.3)$ & 79 & $(63.7)$ & 1.294 & 0.255 \\
\hline Female & 140 & $(42.2)$ & 192 & $(57.8)$ & & \\
\hline \multicolumn{7}{|l|}{ Marital status of student } \\
\hline Single & 183 & $(40.5)$ & 269 & $(59.5)$ & 0.149 & $1.000^{+}$ \\
\hline Married & 2 & $(50.0)$ & 2 & $(50.0)$ & & \\
\hline \multicolumn{7}{|l|}{ Socioeconomic group } \\
\hline B40 & 46 & $(43.4)$ & 60 & $(56.6)$ & & \\
\hline M40 & 50 & $(42.4)$ & 68 & $(57.6)$ & 2.434 & 0.296 \\
\hline $\mathrm{T} 20$ & 56 & $(35.0)$ & 104 & $(65.0)$ & & \\
\hline \multicolumn{7}{|l|}{ Marital status of parent } \\
\hline Married & 169 & $(39.8)$ & 256 & $(60.2)$ & 1.682 & 0.195 \\
\hline Divorce/ separated & 16 & $(51.6)$ & 15 & $(48.4)$ & & \\
\hline \multicolumn{7}{|l|}{ Smoking } \\
\hline No & 183 & $(40.7)$ & 267 & $(59.3)$ & 0.132 & 0.716 \\
\hline Yes & 2 & $(33.3)$ & 4 & $(66.7)$ & & \\
\hline \multicolumn{7}{|l|}{ Physical activity } \\
\hline No & 119 & $(40.1)$ & 178 & $(59.9)$ & 0.004 & 0.948 \\
\hline Yes & 63 & $(40.4)$ & 93 & $(59.6)$ & & \\
\hline \multicolumn{7}{|l|}{$\begin{array}{l}\text { Family members passed away within } \\
\text { six months }\end{array}$} \\
\hline No & 169 & $(41.3)$ & 240 & $(58.7)$ & 0.926 & 0.336 \\
\hline Yes & 16 & $(34.0)$ & 31 & $(66.0)$ & & \\
\hline \multicolumn{7}{|l|}{$\begin{array}{l}\text { Family history of psychiatric } \\
\text { disorder }\end{array}$} \\
\hline No & 173 & $(41.1)$ & 248 & $(58.9)$ & 0.621 & 0.431 \\
\hline Yes & 12 & $(34.3)$ & 23 & (65.7) & & \\
\hline $\begin{array}{l}\text { Pages of Quran read per week } \\
\text { median (IQR) }\end{array}$ & 14 & (14) & 12 & (13) & & $0.298^{\#}$ \\
\hline $\begin{array}{l}\text { Days of tahajjud per week median } \\
\text { (IQR) }\end{array}$ & 1 & (3) & 1 & $(2)$ & & $0.037^{\#}$ \\
\hline Depression & & & & & 20.598 & $<0.001$ \\
\hline No & 136 & (48.9) & 142 & (51.1) & & \\
\hline Yes & 49 & $(27.5)$ & 147 & $(72.5)$ & & \\
\hline \multicolumn{7}{|l|}{ Anxiety } \\
\hline No & 116 & (51.1) & 111 & (48.9) & 20.792 & $<0.001$ \\
\hline Yes & 69 & (30.1) & 160 & $(69.1)$ & & \\
\hline \multicolumn{7}{|l|}{ Stress } \\
\hline No & 157 & (46.7) & 179 & (53.3) & 20.068 & $<0.001$ \\
\hline Yes & 28 & $(23.3)$ & 92 & (76.7) & & \\
\hline
\end{tabular}

${ }^{+}$Fisher's exact test $\quad$ Mann-Whitney $U \quad x^{2}$ chi square 
Table IV: Simple and multiple logistic regression to determine factors associated with poor sleep quality.

\begin{tabular}{|c|c|c|c|c|c|c|}
\hline \multicolumn{7}{|c|}{ Simple logistic regression } \\
\hline Variables & & B & Wald & $\mathrm{AOR}^{+}$ & $95 \%$ C.I ${ }^{\#}$ & $P$ \\
\hline \multicolumn{7}{|c|}{ Level of study } \\
\hline & $\begin{array}{l}\text { Pre-clinical } \\
\text { (reference) }\end{array}$ & & & & & \\
\hline & Clinical & -0.63 & 10.25 & 0.53 & $0.36-0.78$ & $0.001^{*}$ \\
\hline \multicolumn{7}{|c|}{ Tahajjud (night per week) } \\
\hline & $\begin{array}{l}0 \text { time } \\
\text { (reference) }\end{array}$ & & & & & \\
\hline & $\geq 1$ time & -0.14 & 5.59 & 0.87 & $0.77-0.98$ & $0.018^{*}$ \\
\hline \multicolumn{7}{|c|}{ Depression } \\
\hline & No (reference) & & & & & \\
\hline & Yes & 0.92 & 20.10 & 2.52 & $1.68-3.78$ & $<0.001^{*}$ \\
\hline \multicolumn{7}{|l|}{ Anxiety } \\
\hline & No (reference) & & & & & \\
\hline & Yes & 0.89 & 20.42 & 2.42 & $1.65-3.56$ & $<0.001^{*}$ \\
\hline \multicolumn{7}{|l|}{ Stress } \\
\hline & No (reference) & & & & & \\
\hline & Yes & 1.06 & 19.14 & 2.88 & $1.79-4.63$ & $<0.001^{*}$ \\
\hline \multicolumn{7}{|c|}{ Multiple logistic regression } \\
\hline \multicolumn{7}{|c|}{ Level of study } \\
\hline & $\begin{array}{l}\text { Pre-clinical } \\
\text { (reference) }\end{array}$ & & & & & \\
\hline & Clinical & -0.83 & 15.46 & 0.44 & $0.29-0.66$ & $<0.001^{*}$ \\
\hline \multicolumn{7}{|c|}{ Tahajjud (night per week) } \\
\hline & $\begin{array}{l}0 \text { time } \\
\text { (reference) }\end{array}$ & & & & & \\
\hline & 1 time & -0.12 & 3.54 & 0.88 & $0.78-1.01$ & 0.060 \\
\hline \multicolumn{7}{|c|}{ Depression } \\
\hline & No (reference) & & & & & \\
\hline & Yes & 0.54 & 4.31 & 1.71 & $1.03-2.83$ & $0.038^{*}$ \\
\hline \multicolumn{7}{|l|}{ Anxiety } \\
\hline & No (reference) & & & & & \\
\hline & Yes & 0.46 & 3.58 & 1.58 & $0.98-2.53$ & 0.059 \\
\hline \multicolumn{7}{|l|}{ Stress } \\
\hline & No (reference) & & & & & \\
\hline & Yes & 0.55 & 3.32 & 1.74 & $0.96-3.16$ & 0.068 \\
\hline
\end{tabular}

${ }^{*} \mathrm{p}<0.05$ is significant ${ }^{\#} 95 \%$ confidence interval ${ }^{+}$Adjusted Odd Ratio

Nagelkerke R Square was 0.148 . This implies that only $14 \%$ of variation in this study was explained

slightly lower prevalence of poor sleep quality compared to students from University Putra Malaysia and University Malaya. ${ }^{8}$ Different sample population background and curriculum between these universities could be the main reasons for the differences in the prevalence of poor sleep quality among medical students. Besides, studies done in public universities in Malaysia including our study had yielded a higher prevalence of poor sleep quality compared to those from private universities. ${ }^{6-8}$ Further research needs to be done to analyse the reason for the differences in sleep quality level between the public and private universities medical students.

Although only 47 respondents had stated the main reason why they experienced troublesome sleep, it was worrisome to find that the main reason for it was due psychological or medical problems (36.2\%) such as back pain, headache, palpitation, anxiety and stress. This was followed by caffeine intake (31.9\%) and exam related problem (14.9\%). Three 
percent of respondents had used sleep medication to assist them to sleep. It was also reported in other studies that those with sleep problem took sleep medication as the solution. ${ }^{5,7}$ This requires early intervention before complications start to develop, such as medication dependence. Among the interventions include educating the students on how to control caffeine dependency problem and how to effectively manage their preparation for the examination.

Our study revealed that respondents in the clinical years were less likely $(\mathrm{AOR}=0.53,95 \% \mathrm{Cl}=0.36$ 0.78 ) to have poor sleep quality compared to preclinical students. This was consistent with two previous studies where the pre-clinical students were found to be more prone to have poor sleep quality. ${ }^{10,16}$ Contrarily, a local study revealed that clinical students had a higher risk to develop poor sleep quality. ${ }^{6}$ This inconsistency may be due to the higher proportion of clinical students compared to pre-clinical students in our study. It was postulated that students in pre-clinical years may have problems to cope with the new environment and still lacks time management skills. Besides, a higher number of lectures and study load during the preclinical years may be one of the factors that lead to poor sleep quality. ${ }^{10}$

Even though there was limited research done to study the relationship between spiritual factors and sleep quality, we found that performing tahajjud has a significant association with poor sleep quality from bivariate analysis. More interestingly, simple logistic regression showed that those performing tahajjud were less likely to have poor sleep quality compared to those who did not.

However, there was no significant relationship found between performing tahajjud with sleep quality after adjusting for the confounders $(95 \% \mathrm{Cl}=0.78$ 1.01, $p=0.060$ ). An almost similar study done in Saudi Arabia found that early morning prayer (Subuh) had no impact on sleep quality. ${ }^{17}$ It is very important to share this finding with others including Muslim and non-Muslim. Some may think that tahajjud prayer may lead to poor sleep quality and subsequently affect their daytime performance. However, our result proves that assumption to be wrong. As an Islamic university, we should encourage our students to perform as much tahajjud as they desire.
From our multivariate analysis, students with depression were at higher risk to have poor sleep quality $(A O R=1.71,95 \% \mathrm{Cl}=1.03-2.83, \mathrm{p}=0.038)$. This finding was consistent with the studies done in the Middle East and local setting where the prevalence of poor sleep quality was significantly higher among students with depression. ${ }^{10,18,19}$ Additionally, many previous studies had found that students with anxiety or stress had a higher risk of having poor sleep quality. $(4,9,19-22)$ However, our study found that anxiety $(\mathrm{AOR}=1.58,95 \% \mathrm{Cl}=0.98-2.53, \mathrm{p}=0.059)$ and stress (AOR=1.74, 95\% Cl=0.96-3.16, $\mathrm{p}=0.068$ ) were both confounders for poor sleep quality. This inconsistency might be due to the fact that we had different population size and almost a quarter of our respondents were having normal stress level. Nevertheless, various studies had concluded that there was a clear correlation between sleep disorders and psychiatric problems. ${ }^{23}$

One of the limitations of this study was that the data obtained through self-reporting were prone to recall bias. Besides, there could be underreporting bias from the respondents such as in total household income, tahajjud performance and Al-Quran recitation. We tried to maintain the quality of data by using validated and reliable questionnaires. Our study was also more prone to selection bias as we conducted this study by convenient sampling method. We decided to choose this sampling method because of time constraint and availability of the clinical students. However, the response rate was high (91.2\%) and this could minimise the selection bias and we could potentially generalise the findings to all medical students in IIUM. Other than that, the main distinctive part of our study compared to other local studies was that our study involved the spiritual aspect such as tahajjud which has been found to affect the sleep quality. We also analysed the direct relationship between sleep quality and mental health.

\section{CONCLUSION}

In conclusion, the prevalence of poor sleep quality among IIUM medical students was high. Those who were in the pre-clinical years and have depression symptoms were independently associated with poor sleep quality. Therefore, the responsible authority should plan for effective measures to handle this issue which will benefit the students and later the community which they will serve in the future. To 
illustrate, education on time management should be implemented to help students to schedule and manage their daily tasks appropriately and efficiently. in an appropriate way. Furthermore, regular screening for mental health problems among medical students is necessary for early detection and intervention.

\section{Conflict of Interest}

There was no conflict of interest to declare.

\section{ACKNOWLEDGEMENT}

The authors wish to thank Kulliyyah of Medicine, International Islamic University Malaysia and all medical students of the study location for providing us cooperation to ensure the success of this study.

\section{REFERENCES}

1. Ferrara M, De Gennaro L. How much sleep do we need? Sleep Med Rev [online]. 2001; 5:155-79. Available from: http://www.ncbi.nlm.nih.gov/ pubmed/12531052. Accessed October 13, 2018.

2. Buboltz WC, Soper B, Brown F, Jenkins S. Treatment approaches for sleep difficulties in college students. Couns Psychol Q [online]. 2002; 15:229-37. Available from: http:// www.tandfonline.com/doi/ full/10.1080/09515070210151788. Accessed October 13, 2018.

3. Pilcher JJ, Ginter DR, Sadowsky B. Sleep quality versus sleep quantity: Relationships between sleep and measures of health, well-being and sleepiness in college students. J Psychosom Res [online]. 1997; 42:583-96. Available from: https://www.sciencedirect.com/science/ article/pii/S0022399997000044?via\%3Dihub. Accessed October 13, 2018.

4. Almojali Al, Almalki SA, Alothman AS, Masuadi EM, Alaqeel MK. The prevalence and association of stress with sleep quality among medical students. J Epidemiol Glob Health [online]. 2017;7:169-74. Available from: http:// dx.doi.org/10.1016/j.jegh.2017.04.005. Accessed October 13, 2018.

5. Surani AA, Zahid S, Surani A, Ali S, Mubeen M, Khan RH. Sleep quality among medical students of Karachi, Pakistan. J Pak Med Assoc. 2015; 65:380-2.

6. Zailinawati AH, Teng CL, Chung YC, Teow TL, Lee PN, Jagmohni KS. Daytime sleepiness and sleep quality among Malaysian medical students. Med J Malaysia. 2009; 64:108-10.

7. Lai P, Say Y. Associated Factors of Sleep Quality and Behavior among Students of Two Tertiary Institutions in Northern Malaysia. Med J Malaysia. 2013; 68:195-202.

8. Ngu ST, Masalamany K, Manan AA, Adam NK. Sleep quality among pre-clinical medical students in Universiti Putra Malaysia and Universiti Malaya. Malaysia Educ Med J. 2017; 9:23-31.

9. Alsaggaf MA, Wali SO, Merdad RA, Merdad LA. Sleep quantity, quality, and insomnia symptoms of medical students during clinical years: Relationship with stress and academic performance. Saudi Med J. 2016; 37:173-82.

10. SK J, NK I, AN F, et al. Sleep Quality among Medical Students at King Abdulaziz University: A Cross-sectional Study. J Community Med Health Educ [online]. 2017;07. Available from: https:// www.omicsonline.org/open-access/sleepquality-among-medical-students-at-kingabdulaziz-university-a-crosssectional-study-2161 -0711-1000561-94560. Accessed October 13, 2018.

11. Siddiqui AF, Al-Musa $\mathrm{H}, \mathrm{Al}-\mathrm{Amri} \mathrm{H}$, et al. Sleep Patterns and Predictors of Poor Sleep Quality among Medical Students in King Khalid University, Saudi Arabia. Malays J Med Sci [online]. 2016;23:94-102. Available from: http://www.ncbi.nlm.nih.gov/ pubmed/28090183\%0Ahttp:// www.pubmedcentral.nih.gov/ articlerender.fcgi?artid=PMC5181996. Accessed October 13, 2018.

12. Salam A, Mahadevan R, Rahman AA, et al. Stress among First and Third Year Medical Students at University Kebangsaan Malaysia. Pakistan J Med Sci. 2015;31:169-73.

13. Buysse DJ, Reynolds CF, Monk TH, et al. The Pittsburgh Sleep Quality Index: a new instrument for psychiatric practice and research. Psychiatry Res [online]. 1989;28:193213. Available from: http:// eutils.ncbi.nlm.nih.gov/entrez/eutils/ elink.fcgi?dbfrom=pubmed\%7B\&\%7Did=2748771\% 7B\&\%7Dretmode=ref\%7B\&\%7Dcmd=prlinks. Accessed October 13, 2018.

14. Abdulrahman. Al-kafi \# 793: strengthen yourself and how to do it [online]. 2018. Available from: https://muftiwp.gov.my/en/artikel/al-kafi-li-al -fatawi/2543-al-kafi-793-maksud-tahajjud-dan- 
cara-melakukannya. Accessed January 13, 2019.

15. Henry JD, Crawford JR. The short-form version of the Depression Anxiety Stress Scales (DASS-

21): Construct validity and normative data in a large non-clinical sample. $\mathrm{Br} \mathrm{J}$ Clin Psychol. 2005; 44:227-39.

16. Ayala EE, Berry R, Winseman JS, Mason HRC. A Cross-Sectional Snapshot of Sleep Quality and Quantity among US Medical Students. Acad Psychiatry [online]. 2017; 41:664-8. Available from: http://dx.doi.org/10.1007/s40596-0160653-5. Accessed October 13, 2018.

17. Bahammam A, Sharif M, Spence D, PandiPerumal S. Sleep architecture of consolidated and split sleep due to the dawn (Fajr) prayer among Muslims and its impact on daytime sleepiness. Ann Thorac Med. 2012; 7:36-41.

18. Fawzy M, Hamed SA. Prevalence of psychological stress, depression and anxiety among medical students in Egypt. Psychiatry Res [online]. 2017; 255:186-94. Available from: http://

dx.doi.org/10.1016/j.psychres.2017.05.027. Accessed October 13, 2018.

19. Kesintha A, Rampal L, Sidik SM, Thevandran K. Prevalence and predictors of poor sleep quality among secondary school students in Gombak District, Selangor. Med J Malaysia. 2018;73.

20. Rezaei M, Khormali M, Akbarpour S, SadeghniiatHagighi K, Shamsipour M. Sleep quality and its association with psychological distress and sleep hygiene: A crosssectional study among preclinical medical students. Sleep Sci. 2018; 11:274-80.

21. De Souza Neta AM, Fink Santos Neves JPD, Barreto ÍDDC, Freitas Trindade LMD. Medical and Law Graduates and their sleep disorders: Daytime oversleep and Risk Factors. J Heal Biol Sci. 2018; 6:364.

22. Wellen D, D P, Samuels ÃJ, et al. Utility of the Leyton Obsessional Inventory. Depress Anxiety. 2006; 6:1-6.

23. Azad MC, Fraser K, Rumana N, et al. Sleep disturbances among medical students: a global perspective. J Clin Sleep Med [online]. 2015; 11:69-74. Available from: http:// www.pubmedcentral.nih.gov/articlerender.fcgi? artid $=4265662 \&$ tool $=$ pmcentrez\&rendertype $=a b s$ tract. Accessed October 13, 2018. 